\title{
Representasi Siswa dengan Kemampuan Matematis Tinggi dalam Memecahkan Masalah Matematika
}

\author{
Nabyllah Agnielia Mulyadi ${ }^{1}$, Janet Trineke Manoy ${ }^{2}$ \\ ${ }^{1,2}$ Program Studi Pendidikan Matematika, Fakultas Matematika dan Ilmu Pengetahuan Alam, Universitas Negeri Surabaya, \\ Jl. Ketintang, Ketintang, kecamatan Gayungan Kota Surabaya \\ mnabyllah@gmail.com
}

\begin{abstract}
Representation is one of the abilities that students use to solve a problem because representation is a supporting tool for students to construct a problem to be more concrete. Therefore, teachers need to know the ability to represent students as a basic ability to solve a problem. This research is a qualitative descriptive study that aims to analyze the representation of students with high mathematical ability to solve mathematical problems. The instruments of the study are researchers as the primary instruments, tests of mathematics ability and the value of student assignments on equation materials and quadratic functions, and interview guidelines. The research subject consists of 3 students of class IX of SMP Negeri 16 Surabaya who have high mathematical abilities. The results of the study, which were analyzed using indicators adapted from Castellanos type of representation and Polya problem-solving stages, showed students with high mathematical abilities can use 3 forms of representation in solving problems, namely verbal, symbolic, and visual representations. At the stage of understanding the problem, S1 and S3 give rise to the same type of representation that is verbal, visual and, while S2 gives rise to visual and symbolic representations. In the stage of drawing up a plan, S2 and S3 give rise to the same type of representation that is verbal, visual, and symbolic representation, while $S 1$ uses verbal and symbolic representations. In the problem-solving stage, S1 and S2 use the same type of representation that is symbolic representation, while $\mathrm{S} 3$ uses verbal and symbolic representations. In the re-examining stage, S1, S2 and S3 use the same representations of verbal, visual and symbolic representations.
\end{abstract}

Keywords: Representation, Problem solving, Mathematics problem

\begin{abstract}
Abstrak
Representasi adalah salah satu kemampuan yang digunakan siswa untuk memecahkan suatu masalah karena representasi merupakan alat pendukung siswa untuk mengonstruksi suatu masalah menjadi lebih konkret. Oleh karena itu guru perlu mengetahui kemampuan representasi siswa sebagai kemampuan dasar untuk memecahkan suatu masalah. Penelitian ini merupakan penelitian deskriptif kualitatif yang bertujuan untuk menganalisis representasi siswa dengan kemampuan matematis tinggi dalam memecahkan masalah matematika. Instrumen dari penelitian ini adalah peneliti sebagai instrumen utama, tes kemampuan matematika dan nilai tugas siswa pada materi persamaan dan fungsi kuadrat, dan pedoman wawancara. Subjek penelitian terdiri dari 3 siswa kelas IX SMP Negeri 16 Surabaya yang memiliki kemampuan matematis tinggi. Hasil penelitian yang dianalisis menggunakan indikator yang diadaptasi dari tipe representasi Castellanos dan tahapan pemecahan masalah Polya, menunjukkan siswa dengan kemampuan matematis tinggi dapat menggunakan 3 bentuk representasi dalam memecahkan masalah, yaitu representasi verbal, simbolik dan visual. Pada tahap memahami masalah, S1 dan S3 memunculkan tipe representasi yang sama yaitu representasi verbal, visual dan, sementara itu S2 memunculkan representasi visual dan simbolik. Pada tahap menyusun rencana, S2 dan S3 memunculkan tipe representasi yang sama yaitu representasi verbal, visual dan simbolik, sementara itu S1 menggunakan representasi verbal dan simbolik. Pada tahap menyelesaikan masalah, S1 dan S2 menggunakan tipe representasi yang sama yaitu representasi simbolik, sementara itu S3 menggunakan representasi verbal dan simbolik. Pada tahap memeriksa kembali, S1, S2 dan S3 menggunakan representasi yang sama yaitu representasi verbal, visual dan simbolik.
\end{abstract}

Kata Kunci: Representasi, Pemecahan Masalah, Masalah Matematika

Copyright (c) 2022 Nabyllah Agnielia Mulyadi, Janet Trineke Manoy $\triangle$ Corresponding author: Nabyllah Agnielia Mulyadi

Email Address: mnabyllah@gmail.com (Jl. Ketintang, Ketintang, kecamatan Gayungan Kota Surabaya)

Received 07 January 20212 Accepted 26 January 2022, Published 28 January 2022

\section{PENDAHULUAN}

Sejak pandemi Covid-19, Indonesia menerapkan aturan pembatasan kegiatan untuk semua bidang termasuk pendidikan. Akibat dari pembatasan kegiatan tersebut, sekolah melakukan proses 
pembelajaran dalam jaringan (daring) yang dilaksanakan dari rumah (Delima \& Cahyawati, 2021). Walaupun pembelajaran daring, tujuan dari pembelajaran matematika masih berdasarkan pada kurikulum 2013 yaitu menggunakan pendekatan ilmiah melalui mengamati, menanya, mencoba, menalar, menyaji, dan mencipta (Kurniasih \& Sani, 2014). Proses penilaian pada kurikulum 2013 juga menekankan untuk mengukur proses kerja siswa bukan hanya hasil kerja siswa, salah satu proses yang dimaksud dalam pembelajaran adalah proses memecahkan masalah (Mulyono \& Hadiyanti, 2018). Sebagian besar siswa memandang negatif matematika sebagai mata pelajaran yang sulit (Kristia et al., 2021), sehingga mempengaruhi kemampuan siswa dalam proses pembelajaran salah satunya kemampuan pemecahan masalah (Kuncoro et al., 2018). Padahal kemampuan pemecahan masalah sangat penting dalam pendidikan mulai dari sekolah dasar hingga sekolah tinggi karena pemecahan masalah merupakan salah satu kompetensi dasar pembelajaran matematika, melalui pemecahan masalah siswa dapat mempelajari ide matematika dan keterampilan matematika (Laili, 2019).

Pemecahan masalah adalah proses seseorang menemukan solusi dari sebuah masalah dengan menggunakan semua kemampuan yang dimiliki (Annizar et al., 2020). Beberapa penelitian telah menjelaskan kesulitan siswa dalam menyelesaikan masalah matematika, seperti penelitian yang dilakukan oleh (Jupri \& Drijvers, 2016) menjelaskan bahwa kesulitan siswa dalam menyelesaikan suatu masalah karena belum mampu menentukan model yang sesuai dengan masalah matematika hal ini sejalan dengan penelitian (Phonapichat et al., 2014) yang menjelaskan kesulitan siswa dalam menyelesaikan masalah matematika adalah siswa belum mampu untuk memahami kata kunci masalah. Kedua pernyataan tersebut diperkuat lagi oleh penelitian yang dilakukan oleh (Hadi et al., 2018) yang menjelaskan bahwa kesulitan siswa dalam menyelesaikan suatu masalah matematika yaitu kurang mampu untuk memahami masalah, menentukan rumus yang sesuai dengan masalah, dan kesulitan membuat rencana penyelesaian masalah. Kesulitan - kesulitan yang dialami siswa dalam menyelesaikan masalah matematika, dikarenakan lemahnya kemampuan representasi siswa, sehingga dapat dikatakan pemecahan masalah berkaitan dengan kemampuan representasi yang dimiliki oleh seseorang, karena untuk memecahkan masalah butuh keterampilan menyampaikan ide dalam berbagai bentuk, seperti kata-kata, simbol atau gambar, keterampilan menyampaikan ide ini disebut sebagai kemampuan representasi (Utami et al., 2019).

Hal serupa juga diungkapkan oleh NCTM yang menempatkan pemecahan masalah dan representasi sebagai dua dari lima kemampuan dasar penting yang perlu dimiliki oleh seorang siswa (NCTM, 1998). Representasi menjadi kemampuan penting yang harus dimiliki siswa, karena representasi merupakan alat pendukung siswa untuk mengonstruksi suatu masalah abstrak menjadi konkret melalui beragam cara (Widakdo, 2017). Terdapat dua macam representasi, yaitu representasi eksternal dan representasi internal. Representasi eksternal dapat dikomunikasikan seperti gambar, sketsa, persamaan dan tulisan. Sedangkan representasi internal berupa gambaran yang berada dalam pikiran seseorang dan sulit untuk dijelaskan (Mainali, 2021). Beberapa tipe representasi eksternal 
yang digunakan siswa untuk merepresentasikan suatu masalah terbagi yaitu representasi verbal, representasi visual dan representasi simbolik (Madrid et al., 2015).

Beberapa penelitian telah mengangkat topik proses pemecahan masalah siswa seperti penelitian (Bernard et al., 2018; Lahinda \& Jailani, 2015) dan juga mengangkat topik kemampuan representasi seperti penelitian (Herdiman et al., 2018; Mulyadi \& Fiangga, 2021). Namun belum ditemukan penelitian yang menganalisis representasi siswa dalam menyelesaikan masalah materi persamaan kuadrat. Penting bagi pendidik untuk mengetahui kemampuan representasi siswa, karena kemampuan representasi dapat menunjukkan kemampuan siswa dalam menyelesaikan suatu masalah matematika (Andhani, 2016).

\section{METODE}

Metode yang digunakan dalam penelitian ini adalah metode deskriptif kualitatif karena peneliti sebagai instrumen utama yang mengambil data penelitian dan ingin menjabarkan representasi siswa dalam memecahkan masalah (Shidiq \& Choiri, 2019). Instrumen lain yang digunakan dalam penelitian ini terdiri dari tes kemampuan matematika, nilai tugas siswa pada materi persamaan kuadrat dan pedoman wawancara. Tes kemampuan matematika terdiri dari 1 soal uraian (gambar 1) yang telah divalidasi oleh dosen pendidikan matematika Universitas Negeri Surabaya.

1. Pada pagi hari di sebuah gedung isolasi untuk pasien Covid-19, Dokter menyarankan kepada pasien tanpa gejala untuk berolahraga ringan seperti berjalan kaki mengelilingi lapangan didepan gedung tersebut yang berbentuk persegi panjang. Dokter menyarankan untuk berjalan hingga 4000 langkah kaki yang setara dengan 1200 meter. Start berjalan dimulai dari salah satu titik sudut lapangan, diketahui bahwa panjang lapangan adalah 4,5 m lebih dari lebarnya. Setelah berjalan 2,5 kali putaran, salah seorang pasien merasa lelah dan tidak bisa melanjutkan olahraganya, akhirnya perawat berjalan sejauh 22,5 m menjemput pasien tersebut, dari titik awal ke tempat pasien tersebut, melalui diagonal lapangan. Menurut pendapat anda, apakah pasien tersebut terlalu jauh berjalan sehingga dia merasa lelah? Buktikan alasan anda!

Gambar 1. Tes Kemampuan Matematika

Penelitian ini di lakukan di SMP Negeri 16 Surabaya, subjek dalam penelitian ini adalah 3 siswa dengan kemampuan matematis tinggi. Untuk menentukan subjek penelitian, peneliti menggunakan rata-rata nilai tugas siswa pada materi persamaan dan fungsi kuadrat yang dapat dilihat pada tabel 1.

Tabel 1. Kemampuan Matematis Siswa

\begin{tabular}{|c|c|c|c|c|}
\hline No. & Kategori & Nilai & Jumlah Siswa & Persentase \\
\hline 1. & Tinggi & $80-100$ & 15 & $39.47 \%$ \\
\hline 2. & Sedang & $60-79$ & 10 & $26.31 \%$ \\
\hline 3. & Rendah & $0-59$ & 13 & $34.21 \%$ \\
\hline
\end{tabular}

Kemampuan matematis siswa digolongkan menjadi 3 yaitu, kemampuan tinggi dengan rata-rata nilai 80-100, kemampuan sedang dengan rata-rata nilai 60-79 dan kemampuan rendah dengan rata- 
rata nilai 0-59. Hasil rata-rata nilai tugas siswa pada materi persamaan dan fungsi kuadrat, diperoleh $39.47 \%$ siswa memiliki kemampuan matematis tinggi, $26.31 \%$ siswa memiliki kemampuan matematis sedang dan $34.21 \%$ siswa memiliki kemampuan matematis rendah. Setelah menggolongkan kemampuan matematis siswa, peneliti memilih 3 siswa dengan kemampuan matematis tinggi karena jawaban siswa pada kategori kemampuan matematis sedang dan rendah belum memenuhi kriteria yang peneliti inginkan. Siswa dengan kemampuan matematis tinggi diberikan tes seperti pada gambar 1 , kemudian peneliti menganalisis jawaban siswa menggunakan indikator penelitian pada tabel 2 .

Tabel 2. Indikator Pemecahan Masalah

\begin{tabular}{|c|c|c|c|}
\hline $\begin{array}{l}\text { Langkah } \\
\text { pemecahan } \\
\text { masalah }\end{array}$ & $\begin{array}{l}\text { Kemampuan } \\
\text { Representasi }\end{array}$ & Indikator & Kode \\
\hline \multirow{7}{*}{$\begin{array}{l}\text { Step 1: } \\
\text { Memahami } \\
\text { Masalah }\end{array}$} & \multirow[t]{3}{*}{$\begin{array}{l}\text { Representasi } \\
\text { Verbal }\end{array}$} & $\begin{array}{l}\text { Membaca soal dengan suara keras atau } \\
\text { bergumam }\end{array}$ & $U-11$ \\
\hline & & $\begin{array}{l}\text { Menyampaikan secara lisan masalah yang } \\
\text { diketahui dalam soal dengan mengubah } \\
\text { beberapa kata }\end{array}$ & $U-12$ \\
\hline & & $\begin{array}{l}\text { Menuliskan kembali masalah yang diketahui } \\
\text { dalam bentuk kata-kata dengan mengubah } \\
\text { beberapa kata }\end{array}$ & $U-13$ \\
\hline & \multirow{2}{*}{$\begin{array}{l}\text { Representasi } \\
\text { Visual }\end{array}$} & Menggambarkan masalah yang diketahui & $U-21$ \\
\hline & & $\begin{array}{l}\text { Menjelaskan secara lisan masalah yang } \\
\text { diketahui menggunakan gerakan tubuh seperti } \\
\text { tangan atau anggota tubuh lainnya }\end{array}$ & $U-22$ \\
\hline & \multirow[t]{2}{*}{$\begin{array}{l}\text { Representasi } \\
\text { Simbolik }\end{array}$} & $\begin{array}{l}\text { Menuliskan masalah yang diketahui } \\
\text { menggunakan ekspresi simbolik }\end{array}$ & $U-31$ \\
\hline & & $\begin{array}{l}\text { Menjelaskan masalah yang diketahui } \\
\text { menggunakan ekspresi simbolik }\end{array}$ & $U-32$ \\
\hline \multirow{6}{*}{$\begin{array}{l}\text { Step 2: } \\
\text { Menyusun } \\
\text { Rencana }\end{array}$} & \multirow[t]{2}{*}{$\begin{array}{l}\text { Representasi } \\
\text { Verbal }\end{array}$} & $\begin{array}{l}\text { Menuliskan strategi penyelesaian masalah } \\
\text { menggunakan kata-kata }\end{array}$ & $D-11$ \\
\hline & & $\begin{array}{l}\text { Menyampaikan secara lisan strategi yang } \\
\text { digunakan untuk menyelesaikan masalah dalam } \\
\text { soal }\end{array}$ & $D-12$ \\
\hline & \multirow[t]{2}{*}{$\begin{array}{l}\text { Representasi } \\
\text { Visual }\end{array}$} & $\begin{array}{l}\text { Menjelaskan strategi yang digunakan untuk } \\
\text { menyelesaikan soal menggunakan gambar }\end{array}$ & $D-21$ \\
\hline & & $\begin{array}{l}\text { Menggambarkan strategi yang digunakan } \\
\text { dalam menyelesaikan soal }\end{array}$ & $D-22$ \\
\hline & \multirow[t]{2}{*}{$\begin{array}{l}\text { Representasi } \\
\text { Simbolik }\end{array}$} & $\begin{array}{l}\text { Menjelaskan strategi yang digunakan untuk } \\
\text { menyelesaikan soal menggunakan simbol }\end{array}$ & $D-31$ \\
\hline & & $\begin{array}{l}\text { Menuliskan strategi yang digunakan dalam } \\
\text { menyelesaikan soal dalam bentuk simbol }\end{array}$ & $D-32$ \\
\hline \multirow{5}{*}{$\begin{array}{l}\text { Step 3: } \\
\text { Menyelesaikan } \\
\text { Masalah }\end{array}$} & \multirow[t]{3}{*}{$\begin{array}{l}\text { Representasi } \\
\text { Verbal }\end{array}$} & $\begin{array}{l}\text { Menuliskan penyelesaian masalah dalam soal } \\
\text { menggunakan kata-kata }\end{array}$ & $C-11$ \\
\hline & & $\begin{array}{l}\text { Menyampaikan secara lisan penyelesaian } \\
\text { masalah dalam soal }\end{array}$ & $C-12$ \\
\hline & & $\begin{array}{l}\text { Menjelaskan secara lisan langkah-langkah yang } \\
\text { digunakan untuk menyelesaikan masalah }\end{array}$ & $C-13$ \\
\hline & \multirow[t]{2}{*}{$\begin{array}{l}\text { Representasi } \\
\text { Visual }\end{array}$} & $\begin{array}{l}\text { Menuliskan penyelesaian masalah dalam soal } \\
\text { menggunakan gambar }\end{array}$ & $C-21$ \\
\hline & & Menjelaskan langkah-langkah yang digunakan & $C-22$ \\
\hline
\end{tabular}


Representasi Siswa dengan Kemampuan Matematis Tinggi dalam Memecahkan Masalah Matematika, Nabyllah Agnielia

\begin{tabular}{|c|c|c|c|}
\hline & & $\begin{array}{l}\text { untuk menyelesaikan masalah dalam bentuk } \\
\text { gambar }\end{array}$ & \\
\hline & $\begin{array}{l}\text { Representasi } \\
\text { Simbolik }\end{array}$ & $\begin{array}{l}\text { Menuliskan penyelesaian masalah dalam soal } \\
\text { menggunakan simbol }\end{array}$ & $C-31$ \\
\hline & & $\begin{array}{l}\text { Menjelaskan langkah-langkah yang digunakan } \\
\text { untuk menyelesaikan masalah dalam bentuk } \\
\text { simbol }\end{array}$ & $C-32$ \\
\hline & & $\begin{array}{l}\text { Menuliskan rumus yang digunakan untuk } \\
\text { menyelesaikan masalah. }\end{array}$ & $C-33$ \\
\hline $\begin{array}{l}\text { Step 4: } \\
\text { Memeriksa }\end{array}$ & $\begin{array}{l}\text { Representasi } \\
\text { Verbal }\end{array}$ & $\begin{array}{l}\text { Membuat kesimpulan jawaban menggunakan } \\
\text { kata-kata }\end{array}$ & $L-11$ \\
\hline Kembali & & $\begin{array}{l}\text { Menyampaikan kesimpulan jawaban secara } \\
\text { lisan }\end{array}$ & $L-12$ \\
\hline & $\begin{array}{l}\text { Representasi } \\
\text { Visual }\end{array}$ & $\begin{array}{l}\text { Membuat kesimpulan jawaban menggunakan } \\
\text { gambar }\end{array}$ & $L-21$ \\
\hline & & $\begin{array}{l}\text { Menyampaikan kesimpulan jawaban secara } \\
\text { lisan menggunakan gambar }\end{array}$ & $L-22$ \\
\hline & $\begin{array}{l}\text { Representasi } \\
\text { Simbolik }\end{array}$ & $\begin{array}{l}\text { Membuat kesimpulan jawaban menggunakan } \\
\text { simbol }\end{array}$ & $L-31$ \\
\hline & & $\begin{array}{l}\text { Menyampaikan kesimpulan jawaban secara } \\
\text { lisan menggunakan simbol }\end{array}$ & $L-32$ \\
\hline
\end{tabular}

(Castellanos et al., 2009; Polya, 2014)

\section{HASIL DAN DISKUSI}

Dari hasil analisis jawaban siswa menggunakan indikator penelitian pada tabel 2, diperoleh hasil kemampuan representasi siswa sebagai berikut.

Tabel 5. Hasil Kemampuan representasi Siswa

\begin{tabular}{|c|c|c|c|c|}
\hline \multirow{2}{*}{ No } & \multirow{2}{*}{ Subjek } & \multicolumn{3}{|c|}{ Indikator Kemampuan Representasi } \\
\cline { 3 - 5 } & $\mathrm{S} 1$ & Verbal & Visual & Simbolik \\
\hline 1 & $\mathrm{~S} 2$ & $D-12, D-12, L-11, L-12$ & $U-21$ & $U-31, D-32, C-31$ \\
\hline 2 & $\mathrm{~S} 3$ & $\begin{array}{c}U-12, D-11, D-12, C-11, \\
L-11, L-12\end{array}$ & $U-21, D-21, D-22$ & $U-31, D-32, C-31$ \\
\hline 3 & $\mathrm{~S} 3$ & $U-21, D-21$ & $U-31, D-31, C-31$, \\
$C-33$
\end{tabular}

\section{Analisis Pemecahan Masalah S1}

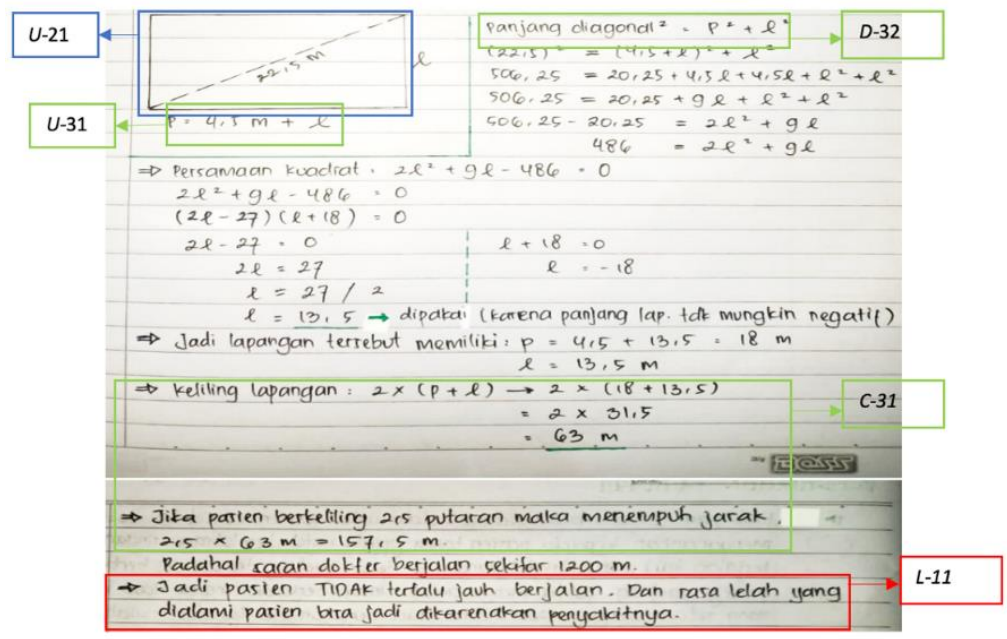

Gambar 2. Pekerjaan S1 
Hasil wawancara $\mathrm{S} 1$ tahap memahami masalah sebagai berikut.

P $\quad$ : "Dapatkah Anda menceritakan masalah yang Anda temukan pada soal?."

S1 : "Bisa Bu, jadi diketahui ada sebuah lapangan yang berbentuk persegi panjang dengan p = $4,5+l$, kemudian ada pasien yang kelelahan dan ada perawat yang membantu pasien tersebut berjalan melalui diagonal lapangan. Pada soal ini, kita diminta pendapat apakah pasien tersebut terlalu jauh berjalan, sehingga ia merasa Lelah. Soal ini berkaitan dengan materi pythagoras, persamaan kuadrat dan keliling bangun datar."

P $\quad$ : "Materi apa yang berkaitan dengan soal tersebut?"

S1 : "Pythagoras, persamaan kuadrat, dan keliling bangun datar"

Berdasarkan hasil pengamatan peneliti terhadap S1 pada tahap memahami masalah, S1 mampu menceritakan kembali masalah pada soal dengan mengubah beberapa kata (U-12). S1 juga mampu mengilustrasikan bentuk lapangan menggunakan bangun datar persegi panjang (U-21) dan menuliskan informasi yang diketahui pada soal menggunakan ekspresi simbolik (U-31). S1 mampu merepresentasikan masalah menggunakan 3 bentuk representasi yaitu representasi verbal, visual dan simbolik.

Hasil wawancara S1 tahap menyusun rencana sebagai berikut.

P : : "Apa langkah awal Anda untuk mengerjakan soal tersebut?."

S1 : : "setelah membaca soal, saya langsung menggambarkan lapangan dengan panjang dan diagonal yang diketahui. Kemudian karena di sini ada diagonal, saya langsung terpikirkan untuk menggunakan rumus Pythagoras Bu”

Berdasarkan hasil pengamatan peneliti terhadap S1 pada tahap menyusun rencana, S1 menceritakan rencana untuk menyelesaikan soal tersebut (D-12), tahap awal S1 menggambarkan lapangan berbentuk persegi panjang kemudian menentukan rumus yang digunakan untuk menyelesaikan masalah pada soal tersebut (D-32). Rumus yang digunakan S1 yaitu pythagoras, karena S1 mengamati bahwa hubungan antara bentuk lapangan dan diagonal lapangan membentuk sebuah segitiga siku-siku. S1 mampu merepresentasikan menggunakan 2 bentuk representasi yaitu representasi verbal dan simbolik.

Hasil wawancara S1 tahap menyelesaikan masalah sebagai berikut.

$P \quad$ : "Apakah Anda menemukan kesulitan saat menyelesaikan soal?.”

S1 : "ada Bu, saya kesulitan untuk mencari akar-akar persamaan kuadrat menggunakan pemfaktoran, menurut saya lebih mudah menggunakan rumus $A B C$ ".

$P \quad: \quad$ :Adakah cara lain yang bisa Anda gunakan untuk mendapatkan jawaban dari soal tersebut?

S1 : "sepertinya bisa Bu, kalau misal yang diketahui dibalik, dari $p=4,5+l$ menjadi $l=p-$ 4,5 .

Jawaban S1 menggunakan cara yang lain dapat dilihat pada gambar 3. 


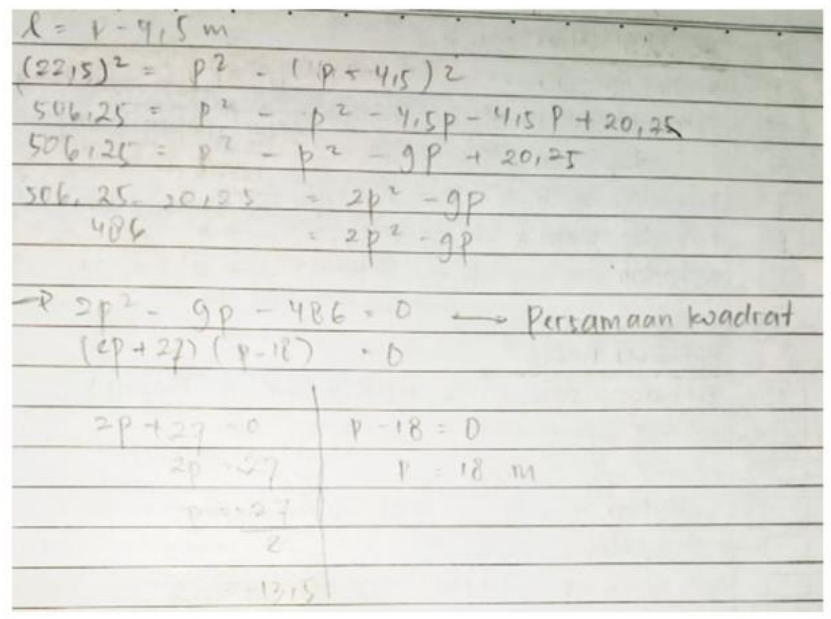

Gambar 3. Pekerjaan S1 dengan cara lain

Berdasarkan hasil pengamatan peneliti terhadap S1 pada tahap menyelesaikan masalah, S1 merepresentasikan penyelesaian menggunakan ekspresi simbolik ( $C-31)$, yaitu menggunakan rumus keliling persegi panjang untuk mengetahui keliling lapangan dan mengetahui jarak tempuh yang dilalui oleh pasien. Berdasarkan hasil wawancara, S1 mengalami kesulitan pada langkah mencari panjang dan keliling menggunakan metode pemfaktoran. S1 mampu menyelesaikan masalah menggunakan 1 bentuk representasi yaitu representasi simbolik.

Hasil wawancara S1 tahap memeriksa kembali sebagai berikut.

: "Saya lihat lagi yang diketahui di soal, seperti saran dokter itu berapa, pasien berkeliling berapa putaran, tinggal dibandingkan. Sehingga saya menemukan bahwa pasien itu tidak terlalu jauh berjalan, melainkan hanya kelelahan biasa mungkin karena penyakitnya".

Berdasarkan hasil pengamatan peneliti terhadap S1 pada tahap memeriksa kembali, S1 membuat kesimpulan dengan mengaitkan jawaban S1 dengan pertanyaan dari soal (L-11 \& L-12). S1 mampu menggunakan 1 bentuk representasi yaitu representasi verbal.

\section{Analisis Pemecahan Masalah S2}

Hasil wawancara S2 tahap memahami masalah sebagai berikut.

$P \quad$ : "Dapatkah Anda menceritakan masalah yang Anda temukan pada soal?."

S2 : "saya menggambarkan hal-hal yang diketahui pada soal, menggambar lapangan dahulu lalu jejak keliling pasien lalu jejak perawat menjemput pasien kemudian saya masuk kerumus karena di sini ketika perawat menjemput pasien itu berbentuk segitiga siku-siku jadi menggunakan rumus pythagoras."

P : : "Materi apa yang berkaitan dengan soal tersebut?"

S2 : "Pythagoras, persamaan kuadrat dan keliling bangun datar" 


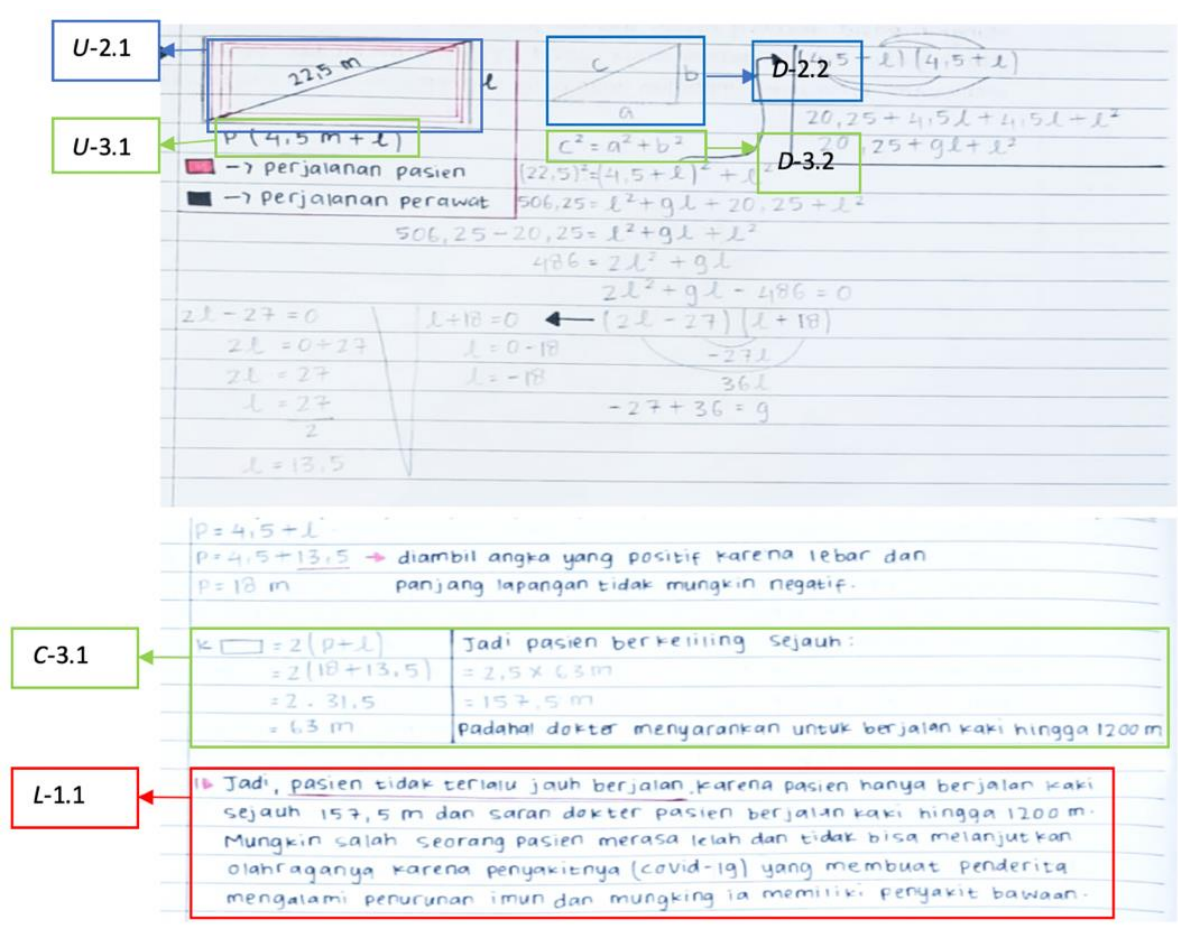

Gambar 4. Pekerjaan S2

Berdasarkan hasil pengamatan peneliti terhadap S2 pada tahap memahami masalah, S2 belum mampu menceritakan kembali masalah pada soal, karena dari hasil wawancara S2 membaca kembali soal. Namun, S2 mampu menggambarkan bentuk lapangan menggunakan bangun datar persegi panjang (U-21). S2 juga mampu menuliskan informasi yang diketahui pada soal menggunakan ekspresi simbolik (U-31). S2 mampu merepresentasikan masalah menggunakan 2 bentuk representasi yaitu representasi visual dan simbolik.

Hasil wawancara S2 tahap menyusun rencana sebagai berikut.

: “Apa langkah awal Anda untuk mengerjakan soal tersebut?.”

$S 2$

: "saya menggambarkan hal-hal yang diketahui pada soal, menggambar lapangan dahulu lalu jejak keliling pasien lalu jejak perawat menjemput pasien kemudian saya masuk kerumus karena di sini ketika perawat menjemput pasien itu berbentuk segitiga siku-siku jadi menggunakan rumus pythagoras"

Berdasarkan hasil pengamatan peneliti terhadap S2 pada tahap menyusun rencana, S2 menceritakan rencana untuk menyelesaikan soal tersebut (D-12), tahap awal S2 menggambarkan lapangan berbentuk persegi panjang disertai dengan jejak jarak tempuh pasien yang digambarkan menggunakan garis berwarna merah, kemudian menentukan rumus yang digunakan untuk menyelesaikan masalah pada soal tersebut (D-32). S2 menggunakan rumus Teorema pythagoras, karena hubungan antara bentuk lapangan dan diagonal lapangan membentuk sebuah segitiga siku-siku (D-22). S2 mampu menggunakan 3 bentuk representasi yaitu representasi verbal, visual dan simbolik.

Hasil wawancara S2 tahap menyelesaikan masalah sebagai berikut. 
Representasi Siswa dengan Kemampuan Matematis Tinggi dalam Memecahkan Masalah Matematika, Nabyllah Agnielia Mulyadi, Janet Trineke Manoy

P $\quad$ : “Apakah Anda menemukan kesulitan saat menyelesaikan soal?.”

S2 : "tidak".

$P \quad$ : "Adakah cara lain yang bisa Anda gunakan untuk mendapatkan jawaban dari soal tersebut?

Berdasarkan hasil pengamatan peneliti terhadap S2 pada tahap menyelesaikan masalah, S2 merepresentasikan penyelesaian yang digunakan menggunakan ekspresi simbolik (C-31), yaitu menggunakan rumus keliling persegi panjang untuk mengetahui keliling lapangan dan mengetahui jarak tempuh yang dilalui oleh pasien. Berdasarkan hasil wawancara, S2 tidak mengalami kesulitan dalam menyelesaikan soal. S2 mampu menggunakan 1 bentuk representasi yaitu representasi simbolik.

Hasil wawancara S2 tahap memeriksa kembali sebagai berikut.

P : : "Bagaimana cara Anda menarik kesimpulan?."

S2 : "Karena pasien tersebut baru berkeliling sejauh 157,5 m sedangkan saran dokter harus berkeliling $1200 \mathrm{~m}$, dan pasien tersebut kelelahan mungkin karena penyakitnya Covid$19 "$.

Berdasarkan hasil pengamatan peneliti terhadap S1 pada tahap memeriksa kembali, S1 membuat kesimpulan dengan cukup baik karena belum mengaitkan jawaban S2 dengan pertanyaan pada soal (L-11 \& L-12). S2 mampu menggunakan 1 bentuk representasi yaitu representasi verbal.

\section{Analisis Pemecahan Masalah S3}

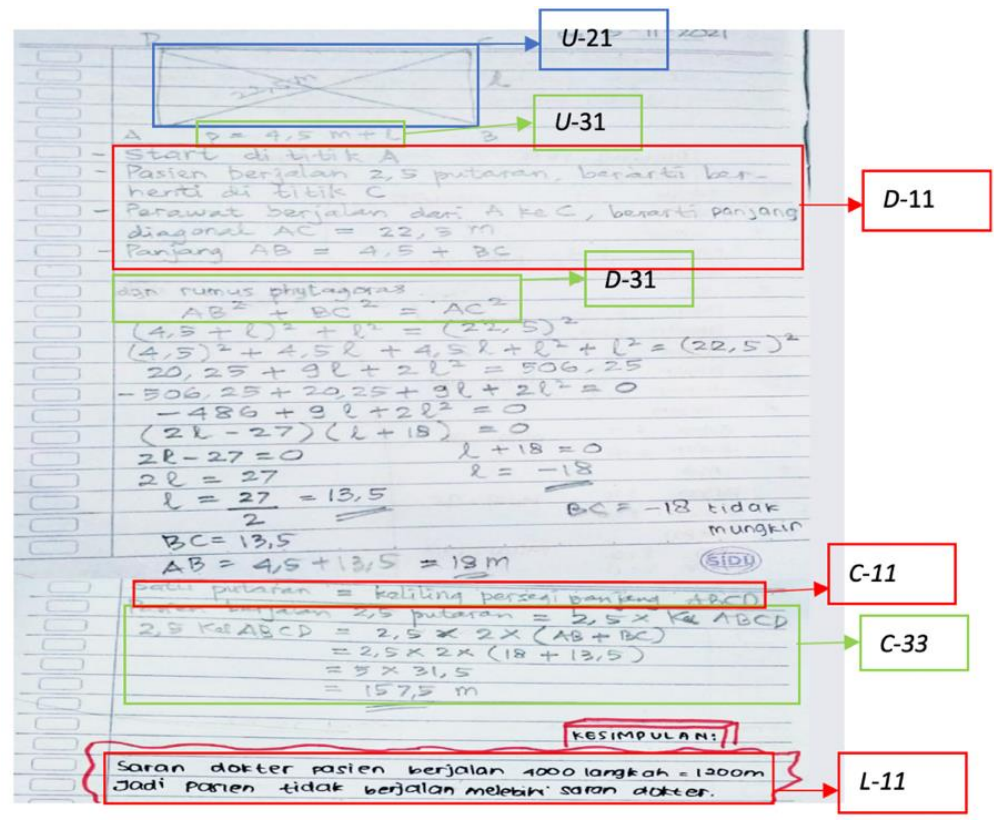

Gambar 5. Pekerjaan S3

Hasil wawancara S3 tahap memahami masalah sebagai berikut. 
: “Jadi di situ saya lihat pertanyaannya itu apakah pasien berjalan terlalu jauh atau tidak, dari permasalahannya itu kita harus tahu dulu berapa meter pasien berjalan apakah melebih atau tidak dari saran yang diberikan dokter."

$P \quad$ : "Materi apa yang berkaitan dengan soal tersebut?"

S3 : "pythagoras, dan keliling bangun datar"

Berdasarkan hasil pengamatan peneliti terhadap S3 pada tahap memahami masalah, S3 mampu menceritakan kembali masalah pada soal dengan mengubah beberapa kata (U-12). S3 juga mampu mengilustrasikan bentuk lapangan menggunakan bangun datar persegi panjang $(U-21)$ dan menuliskan informasi yang diketahui pada soal menggunakan ekspresi simbolik ( $U-31)$. S3 mampu menggunakan 3 bentuk representasi yaitu representasi verbal, visual dan simbolik.

Hasil wawancara S3 tahap menyusun rencana sebagai berikut.

$P \quad$ : "Apa langkah awal Anda untuk mengerjakan soal tersebut?"

S3 : "Awalnya menggambarkan lapangannya dulu, kemudian menuliskan apa saja yang diketahui dan masuk ke langkah penyelesaian"

Tahap menyusun rencana, S3 menceritakan rencana untuk menyelesaikan soal tersebut $(D-12)$, tahap awal S3 menggambarkan lapangan berbentuk persegi panjang, kemudian menuliskan masalah yang diketahui pada soal $(D-11)$, lalu menentukan rumus yang digunakan untuk menyelesaikan masalah pada soal tersebut ( $D$-32). Rumus yang digunakan S3 adalah Teorema pythagoras, karena S3 mengamati bahwa hubungan antara bentuk lapangan dan diagonal lapangan membentuk sebuah segitiga siku-siku (D-21). S3 mampu menggunakan 3 bentuk representasi yaitu representasi verbal, visual dan simbolik.

Hasil wawancara S3 tahap menyelesaikan masalah sebagai berikut.

P : : "Apakah Anda menemukan kesulitan saat menyelesaikan soal?”

S3 : "ya Bu, awalnya saya sulit menggunakan rumus pythagoras".

$P \quad$ : "Adakah cara lain yang bisa Anda gunakan untuk mendapatkan jawaban dari soal tersebut?

S3

: "sepertinya tidak ada Bu"

Berdasarkan hasil pengamatan peneliti terhadap S3 pada tahap menyelesaikan masalah, S3 merepresentasikan penyelesaian yang digunakan menggunakan ekspresi simbolik (C-31), yaitu menggunakan rumus keliling persegi panjang untuk mengetahui keliling lapangan dan mengetahui jarak tempuh yang dilalui oleh pasien. Berdasarkan hasil wawancara, S3 tidak mengalami kesulitan dalam menyelesaikan soal. S3 mampu menggunakan 2 bentuk representasi yaitu representasi verbal dan simbolik.

Hasil wawancara S3 tahap memeriksa kembali sebagai berikut. 
: “Jadi setelah saya menemukan berapa meter pasien itu berjalan, saya menarik kesimpulan karena di situ pasiennya berjalan tidak melebihi saran dokter, jadi saya ambil kesimpulan bahwa pasiennya tidak melebihi saran dokter”.

Berdasarkan hasil pengamatan peneliti terhadap S3 pada tahap memeriksa kembali, S3 membuat kesimpulan dengan baik karena mengaitkan jawaban S3 dengan pertanyaan pada soal (L-11 \& L-12). S3 mampu merepresentasikan masalah menggunakan 1 bentuk representasi yaitu representasi verbal.

Dari 3 subjek dengan kemampuan matematis tinggi, yaitu S1, S2, S3, pada tahap memahami masalah siswa dapat memahami masalah seperti dalam penelitian yang telah dilakukan oleh (Mahardiningrum \& Ratu, 2018) bahwa siswa dengan kemampuan matematis tinggi mampu memahami masalah dengan menuliskan informasi yang diketahui dan ditanyakan pada soal dengan tepat. S1 dan S3 mampu memahami masalah karena mampu merepresentasikan pemahaman tersebut ke dalam 3 bentuk representasi, S1 dan S3 mampu menjelaskan masalah yang ada pada soal, mampu menggambarkan bentuk lapangan dan menggunakan ekspresi simbolik untuk menyatakan informasi yang diketahui pada soal. Sementara itu, S2 memahami masalah dengan merepresentasikan pemahaman tersebut ke dalam 2 bentuk representasi yaitu menggambarkan bentuk lapangan dan menggunakan ekspresi simbolik untuk menyatakan informasi yang diketahui pada soal.

Pada tahap menyusun rencana, S1, S2, S3 menggambarkan bentuk lapangan kemudian S1 dan S3 langsung menggunakan rumus Teorema pythagoras untuk mengetahui panjang dan lebar lapangan, sedangkan S2 setelah menggambarkan lapangan, S2 menganalisis jarak tempuh pasien dengan menggambarkan 2,5 keliling lapangan. Hal ini serupa dengan penelitian (Annizar et al., 2020), penelitian tersebut menyatakan bahwa siswa dengan kemampuan matematis tinggi dapat merencanakan strategi untuk menyelesaikan masalah. Menurut S1 dan S2 materi yang berkaitan dalam penyelesaian masalah ini adalah Teorema pythagoras, persamaan kuadrat dan keliling bangun datar, sedangkan menurut S3 konsep yang berkaitan dengan masalah ini adalah Teorema pythagoras dan persamaan kuadrat.

Dalam tahap menyelesaikan masalah, menurut penelitian (Aryaningsih et al., 2016) siswa dengan kemampuan matematis tinggi mampu menyelesaikan masalah dengan benar, hal ini sesuai dengan hasil dalam penelitian ini, walaupun S1 mengalami kesulitan untuk menggunakan metode pemfaktoran pada penyelesaian persamaan kuadrat, S3 mengalami kesulitan untuk menggunakan rumus Teorema pythagoras, S2 dan S3 mampu menyelesaikan masalah dengan benar. Sementara itu, S2 tidak mengalami kesulitan dalam penyelesaian. Pada tahap memeriksa kembali S1, S2, S3 membuat kesimpulan bahwa pasien tidak terlalu jauh berjalan karena tidak melebihi saran dokter. Berdasarkan penelitian ini menunjukkan bahwa siswa dengan kemampuan matematis tinggi memiliki kemampuan representasi yang baik karena telah mampu menggunakan 3 tipe representasi dalam menyelesaikan masalah matematika yaitu representasi verbal, simbolik dan visual. Siswa dengan kemampuan matematis tinggi juga dapat menyelesaikan soal kemampuan matematika dengan tepat 
dan benar, hasil ini sejalan dengan penelitian yang telah dilakukan oleh (Wilujeng \& Novitasari, 2018) yang menyatakan bahwa kemampuan matematis dalam batas minimal cukup, akan mendukung proses penyelesaian yang dilakukan oleh siswa.

\section{KESIMPULAN}

Berdasarkan hasil dan pembahasan, diperoleh kesimpulan bahwa siswa dengan kemampuan matematis tinggi pada tahap memahami masalah, S1 dan S3 memunculkan tipe representasi yang sama yaitu representasi verbal, visual dan simbolik, sementara itu S2 memunculkan representasi visual dan simbolik. Pada tahap menyusun rencana, S2 dan S3 memunculkan tipe representasi yang sama yaitu representasi verbal, visual dan simbolik, sementara itu S1 menggunakan representasi verbal dan simbolik. Pada tahap menyelesaikan masalah, S1 dan S2 menggunakan tipe representasi yang sama yaitu representasi simbolik, sementara itu S3 menggunakan representasi verbal dan simbolik. Pada tahap memeriksa kembali, S1, S2 dan S3 menggunakan representasi yang sama yaitu representasi verbal, visual dan simbolik. Guru perlu membiasakan siswa untuk menyampaikan ide dalam pemecahan masalah menggunakan berbagai bentuk representasi. Penelitian selanjutnya dapat menganalisis kemampuan pemecahan masalah siswa berdasarkan kemampuan representasi menggunakan materi yang berbeda.

\section{UCAPAN TERIMA KASIH}

Segala puji kehadirat Allah SWT, yang telah melimpahkan rahmat-Nya sehingga peneliti mampu menyelesaikan artikel ilmiah ini. Artikel ilmiah ini dapat diselesaikan juga berkat saran dan dukungan dari berbagai pihak. Peneliti ucapkan terima kasih kepada Ibu Dr. Janet Trineke Manoy, M.Pd selaku dosen pembimbing, Bapak Prof. Dr. Tatag Y.E.S, M.Pd. dan Bapak Dayat Hidayat, M.Pd, M.Si. selaku dewan penguji, orang tua dan seluruh keluarga besar tercinta, teman-teman terdekat yang telah memberikan dukungan dan motivasi, serta reviewer dan editor jurnal Cendekia yang turut memberikan saran dan masukan untuk artikel ilmiah ini. Semoga artikel ini bermanfaat bagi peneliti dan pembaca aamiin.

\section{REFERENSI}

Andhani, R. A. (2016). Representasi Eksternal Siswa dalam Pemecahan Masalah SPLDV Ditinjau dari Kemampuan Matematika. Kreano, Jurnal Matematika Kreatif-Inovatif, 7(2), 179-186. https://doi.org/10.15294/kreano.v7i2.6615

Annizar, A. M., Maulyda, M. A., Khairunnisa, G. F., \& Hijriani, L. (2020). Kemampuan Pemecahan Masalah Matematis Siswa dalam Menyelesaikan Soal PISA pada Topik Geometri. Jurnal Elemen, 6(1), 39-55. https://doi.org/10.29408/jel.v6i1.1688

Aryaningsih, S., Mahmud, R., \& Arsyad, N. (2016). Profil Pemecahan Masalah dalam Pembelajaran Matematika dengan Model Problem Creating pada Siswa Kelas VII-2 SMP Negeri 1 Kota Bima. 
Jurnal Didaktik Matematika, 3(2), 106-118. https://doi.org/10.24815/jdm.v3i2.5688

Bernard, M., Nurmala, N., Mariam, S., \& Rustyani, N. (2018). Analisis Kemampuan Pemecahan Masalah Matematis Siswa SMP Kelas IX Pada Materi Bangun Datar. 2(2), 77-83. https://doi.org/https://doi.org/10.5281/zenodo.1405906

Castellanos, J. L. V., Castro, E., \& Gutiérrez, J. (2009). Representations in problem solving: A case study with optimization problems. Electronic Journal of Research in Educational Psychology, 7(17), 279-308.

Delima, N., \& Cahyawati, D. (2021). Students 'Mathematics Self-Concept, Mathematics Anxiety and Mathematics Self-Regulated Learning during the Covid-19 Pandemic. 15(2), 103-114.

Hadi, S., Retnawati, H., Munadi, S., Apino, E., \& Wulandari, N. F. (2018). The difficulties of high school students in solving higher-order thinking skills problems. Problems of Education in the 21 st Century, 76(4), 520-532. https://doi.org/10.33225/pec/18.76.520

Herdiman, I., Jayanti, K., Pertiwi, K. A., \& Naila N., R. (2018). Kemampuan Representasi Matematis Siswa SMP pada Materi Kekongruenan dan Kesebangunan. Jurnal Elemen, 4(2), 216. https://doi.org/10.29408/jel.v4i2.539

Jupri, A., \& Drijvers, P. (2016). Student difficulties in mathematizing word problems in Algebra. Eurasia Journal of Mathematics, Science and Technology Education, 12(9), 2481-2502. https://doi.org/10.12973/eurasia.2016.1299a

Kristia, D., Habibi, M., Fidya, Y., \& Putra, A. (2021). Analisis Sikap dan Konsep Diri Siswa terhadap Matematika ( Studi Survei pada Siswa MTs Se-Kabupaten Kerinci ). 06(03), 32-46.

Kuncoro, K. S., Junaedi, I., \& Dwijanto. (2018). Analysis of problem solving on project based learning with resource based learning approach computer-aided program. Journal of Physics: Conference Series, 983(1). https://doi.org/10.1088/1742-6596/983/1/012150

Kurniasih, I., \& Sani, B. (2014). Implementasi Kurikulum 2013 Konsep dan Penerapan. Kementrian Pendidikan dan Kebudayaan, 1-162.

Lahinda, Y., \& Jailani, J. (2015). Analisis Proses Pemecahan Masalah Matematika Siswa Sekolah $\begin{array}{llllll}\text { Menengah Pertama. Jurnal Riset Pendidikan Matematika, } 2(1), & 148 .\end{array}$ https://doi.org/10.21831/jrpm.v2i1.7157

Laili, H. (2019). Keefektifan Pembelajaran dengan Menggunakan Pendekatan PBL dan CTL Ditinjau dari Kemampuan Pemecahan Masalah dan Motivasi Belajar. As-Sabiqun, 1(1), 120-141. https://doi.org/10.36088/assabiqun.v1i1.300

Madrid, M. J., Maz-Machado, A., \& León-Mantero, C. (2015). Representations in the SixteenthCentury Arithmetic Books. Universal Journal of Educational Research, 3(6), 396-401. https://doi.org/10.13189/ujer.2015.030607

Mahardiningrum, A. S., \& Ratu, N. (2018). Profil Proses Berpikir Kreatif Matematis Siswa Dalam. 7(1), 39-50. https://doi.org/https://doi.org/10.31980/mosharafa.v7i1.340

Mainali, B. (2021). Representation in teaching and learning mathematics. International Journal of 
Education in Mathematics, Science and Technology, 9(1), 1-21. https://doi.org/10.46328/ijemst.1111

Mulyadi, N. A., \& Fiangga, S. (2021). Analisis Kemampuan Representasi Siswa Dalam $\begin{array}{llll}\text { Menyelesaikan } & \text { Soal } \quad \text { Matematikar } & \text { Soulmath, } & \text { 9(2), 143-152. }\end{array}$ https://doi.org/https://doi.org/10.25139/smj.v9i2.3938

Mulyono, \& Hadiyanti, R. (2018). Analysis of mathematical problem-solving ability based on metacognition on problem-based learning. Journal of Physics: Conference Series, 983(1). https://doi.org/10.1088/1742-6596/983/1/012157

NCTM. (1998). Pssm. Journal of Equine Veterinary Science, 18(11), 719. https://doi.org/10.1016/s0737-0806(98)80482-6

Phonapichat, P., Wongwanich, S., \& Sujiva, S. (2014). An Analysis of Elementary School Students' Difficulties in Mathematical Problem Solving. Procedia - Social and Behavioral Sciences, 116(February), 3169-3174. https://doi.org/10.1016/j.sbspro.2014.01.728

Polya, G. (2014). How to Solve it. In Stochastic Optimization in Continuous Time. https://doi.org/10.1017/cbo9780511616747.007

Shidiq, U., \& Choiri, M. M. (2019). Metode Penelitian Kualitatif di Bidang Pendidikan (A. Mujahidin (ed.)). CV. Nata Karya.

Utami, C. T. P., Mardiyana, \& Triyanto. (2019). Profile of students' mathematical representation ability in solving geometry problems. IOP Conference Series: Earth and Environmental Science, 243(1). https://doi.org/10.1088/1755-1315/243/1/012123

Widakdo, W. A. (2017). Mathematical Representation Ability by Using Project Based Learning on the Topic of Statistics. Journal of Physics: Conference Series, 895(1). https://doi.org/10.1088/1742-6596/895/1/012055

Wilujeng, H., \& Novitasari. (2018). Analisis Kemampuan Pemecahan Masalah Matematika Siswa Smp Negeri 10 Tangerang. Prima: Jurnal Pendidikan Matematika, 2(2), 137-147. 